\title{
Successful Management of Pregnancy and Cesarean Section in a Patient with a Qualitative Variant of Glanzmann Thrombasthenia
}

\author{
Cécile Choux ${ }^{1 *}$, Emmanuel de Maistre ${ }^{2}$, Guillaume Macé ${ }^{1}$, Serge Douvier ${ }^{1}$ and Paul Sagot ${ }^{1}$ \\ ${ }^{1}$ Department of obstetrics and gynecology, Dijon University Hospital, France \\ ${ }^{2}$ Department of Biology, Dijon University Hospital, France
}

Submission: March 03, 2017 ; Published: March 23, 2017

*Corresponding author: Cécile Choux, Department of obstetrics and gynecology, Dijon University Hospital, 14 rue Gaffarel, BP 77908, 21000

Dijon, France, Tel: +33380293852; Fax: +33380293664; Email: cecile.choux@gmail.com

Keywords: Glanzmann thrombasthenia; Qualitative variant; Cesarean section; Pregnancy

\section{Short Communication}

A 19-year-old woman with a qualitative variant of Glanzmann Thrombasthenia (GT) was referred to our department for her first pregnancy. The diagnosis of GT was revealed by epistaxis and gingival bleeding. Her history of bleeding was limited to dental procedures and haemorrhagic rupture of an ovarian cyst under platelet transfusion. Her husband had normal platelet function tests and no consanguinity was suspected. No antiGPIIb-IIIa and anti-HLA antibodies were detected before the pregnancy. No bleeding occurred during the pregnancy. At 38 weeks, the membranes ruptured. A first concentrate of platelets was transfused and labour was induced by ocytocin. It failed, and a C-section was performed. A second concentrate of platelets was administered just before the incision; recombinant activated factor VII (rFVIIa) was available but not used. Post-partum haemorrhage (PPH) did not occur.

Maternal haemoglobin was $11 \mathrm{~g} / \mathrm{dL}$ before and $8.6 \mathrm{~g} / \mathrm{dL}$ after the $\mathrm{C}$-section. Platelet count and ROTEM® test were monitored daily. Two red blood cells and one platelet concentrate were prescribed at day 1 and one platelet concentrate at days 3, 6 and 9 according to the results. Tranexamic acid (TA) and iron were administered for six weeks. No prophylaxis against thrombosis was used. The newborn did not suffer from neonatal thrombocytopenia (platelet count=168 G/L at day 3).

GT is a rare autosomal recessive qualitative or quantitative abnormality of the platelet glycoprotein complex GPIIb-III a, which binds fibrinogen and is required for platelet aggregation.
Patients typically present severe mucocutaneous bleeding [1]. Diagnosis of quantitative GT is confirmed by flow cytometry exploration of GpIIb-IIIa at the platelet surface, which could be used to follow the efficacy of platelet transfusions. Our patient presented qualitative GT, which is associated with less severe bleeding [1]. This is the first report of successful pregnancy and C-section in a patient with a qualitative variant of GT. Currently, there is no specific recommendation for the pregnancy follow-up of such patients. Flow cytometry cannot be used in qualitative GT. Here, we monitored platelet transfusions with ROTEM $®$.

Bleeding can be treated with anti-fibrinolytics including TA or rFVIIa, and red-cell and platelet transfusions. The latter can trigger all immunization leading to platelet refractoriness and therapeutic failure. rFVIIa is expensive and is used only in cases of refractoriness to platelet transfusions [2].

Given the high risk of bleeding in both mother and foetus, peripartum management in GT is challenging. In cases of maternal alloimmunization, transplacental passage of antibodies can induce foetal thrombocytopenia of unpredictable severity and can cause in utero death [3]. Intra partum bleeding was reported in $61 \%$ of GT cases. Platelet alloimmunization was reported in $73 \%$ of pregnancies and associated with four neonatal deaths [1].

No consensus exists concerning the management of pregnancy in GT. Haemophilia centres and obstetric departments must work in close collaboration to plan delivery, postpartum time and neonatal care [2]. Regional anaesthesia 
is contraindicated [4]. Elective C-section is considered only for obstetric indications or a high risk of foetal bleeding [1,4]. Foetal scalp electrodes, scalp blood samples, ventouses or high forceps are contraindicated.

For PPH prophylaxis, two options are available for vaginal delivery: 1-rFVIIa combined with TA, and HLA-selected platelets if bleeding occurs despite this treatment; 2-platelet transfusion and TA associated with rFVIIa only if antibodies are detected. For C-section, platelets and TA are the first-line therapies with surgical drains and regular haemoglobin tests to identify bleeding early. The median time to secondary PPH is 10 days so TA should be maintained for at least two weeks [4].

In our case, platelet transfusions were preferred to rFVIIa because of the good response to platelets for dental procedures and surgery, a low risk of alloimmunization because the defect was qualitative and the cost of rFVIIa.

As an example of successful management of a C-section in a variant GT patient, this case report highlights the challenges of specific care for GT patients and the usefulness of ROTEM® to monitor platelet transfusion.

\section{Acknowledgment}

We are grateful to "Centre de référence des pathologies plaquettaires" and Roselyne d'Oiron MD for monitoring the delivery.

\section{References}

1. Siddiq S, Clark A, Mumford A (2011) A systematic review of the management and outcomes of pregnancy in Glanzmann thrombasthenia. Haemophilia 17(5): e858-e869.

2. Alamelu J, Liesner R (2010) Modern management of severe platelet function disorders. Br J Haematol 149(6): 813-823.

3. Leticee N, Kaplan C, Lemery D (2005) Pregnancy in mother with Glanzmann's thrombasthenia and isoantibody against GPIIb-IIIa: Is there a foetal risk? Eur J Obstet Gynecol Reprod Biol 121(1): 139-142.

4. Bolton-Maggs PH, Chalmers EA, Collins PW, Harrison P, Kitchen S, et al. (2006) A review of inherited platelet disorders with guidelines for their management on behalf of the UKHCDO. Br J Haematol 135(5): 603-633.

\section{Your next submission with Juniper Publishers will reach you the below assets}

- Quality Editorial service

- Swift Peer Review

- Reprints availability

- E-prints Service

- Manuscript Podcast for convenient understanding

- Global attainment for your research

- Manuscript accessibility in different formats ( Pdf, E-pub, Full Text, Audio)

- Unceasing customer service

Track the below URL for one-step submission https://juniperpublishers.com/online-submission.php 